\title{
UPAYA MENINGKATKAN HASIL BELAJAR \\ ILMU PENGETAHUAN SOSIAL MELALUI PEMBELAJARAN KOOPERATIF
}

\author{
Amsunardi \\ Guru Sekolah Dasar Negeri 07 Indralaya Utara \\ Desa Parit Kecamatan Indralaya Utara \\ Kabupaten Ogan Ilir Sumatera Selatan \\ Sur-el: amsunardi700@yahoo.co.id
}

Article info

Article history:

Received: 05/11/2019

Revised : 10/11/2019

Accepted: 12/12/2019

\section{A B S T R A C T}

This study aims to improve student learning outcomes at SDN 07 Indralaya Utara Ogan Ilir Regency through cooperative learning models. This study uses a classroom action research method with the subject of research is the fifth grade students of SDN 07 Indralaya Utara, Ogan Ilir Regency. The results of this study indicate that the ability of students in subject matter fractions, each cycle has increased. Cycle I, the percentage of completeness 58.33\%, students who reach the minimum completeness criteria of seven students. Cycle II with a percentage of completeness $83.33 \%$, students who reached the minimum completeness criteria were ten students. From the two cycles applied, there was an increase in students' abilities in the subject matter of Ethnic Diversity in Indonesia. Based on indicators of success in cycle II, that applied cooperative learning can improve students abilities in the subject matter of Ethnic Diversity in Indonesia.

Keywords:

learning, social science, cooperative learning.

Kata Kunci:

belajar, ilmu

pengetahuan sosial, kooperatif learning.
Penelitian ini bertujuan untuk meningkatkan hasil belajar siswa di SDN 07 Indralaya Utara Kabupaten Ogan Ilir melalui model pembelajaran kooperatif. Penelitian ini meggunakan metode penelitian tindakan kelas dengan subjek penelitiannya adalah siswa kelas V SDN 07 Indralaya Utara Kabupaten Ogan Ilir. Hasil penelitian ini menunjukkan bahwa kemampuan siswa dalam materi pokok pecahan, setiap siklus mengalami peningkatan. Siklus I, nilai persentase ketuntasan 58,33\%, siswa yang mencapai kriteria ketuntasan minimal sebanyak tujuh orang siswa. Siklus II dengan persentase ketuntasan 83,33\%, siswa yang mencapai kriteria ketuntasan minimal sebanyak sepuluh orang siswa. Dari kedua siklus yang diterapkan, terjadi peningkatan kemampuan siswa dalam materi pokok Keragaman Suku Bangsa di Indonesia. Berdasarkan indikator keberhasilan pada siklus II, bahwa pembelajaran kooperatif yang diterapkan dapat meningkatkan kemampuan siswa dalam materi pokok Keragaman Suku Bangsa di Indonesia.
Direktorat Riset dan Pengabdian Masyarakat Universitas Bina Darma 


\section{JURNAL ILMIAH}

BINA EDUKASI

ISSN 1979-8598 E-ISSN: 2655-8378

http://journal.binadarma.ac.id/index.php/jurnalbinaedukasi

Vol. 12, No. 2, Desember 2019, 01 -- 15

\section{PENDAHULUAN}

Mata pelajaran Ilmu Pengetahuan Sosial (IPS) merupakan suatu bahan kajian yang terpadu yang merupakan penyederhanaan, adaptasi, seleksi, dan modifikasi yang diorganisasikan dari konsep-konsep dan keterampilan-keterampilan sejarah, geografi, sosiologi, antropologi, dan ekonomi (Kasim, 2008). IPS adalah mata pelajaran dasar kurikulum sekolah TK sampai SMA/SMK yang (1) mengambil tujuannya dari sifat kewarganegaraan suatu masyarakat yang demokratis yang berhubungan erat dengan bangsa-bangsa dan orang-orang di dunia, (2) mengambil sebagian besar konten materi pelajarannya dari sejarah, ilmu-ilmu sosial dan (3) diajarkan dengan cara merefleksikan kesadaran pribadi, sosial dan ilmu pengalaman kultural dan perkembangan siswa. Fungsi mata pelajaran IPS di SD adalah untuk mengembangkan kemampuan dan sikap rasional tentang gejala-gejala sosial, serta kemampuan tentang perkembangan masyarakat Indonesia dan masyarakat dunia di masa lampau dan masa kini. Adapun ruang lingkup mata pelajaran IPS meliputi substansi materi ilmu-ilmu sosial yang bersentuhan dengan masyarakat, gejala masalah dan peristiwa sosial tentang kehidupan masyarakat. Oleh karena itu, pengajaran IPS harus menggali materi-materi yang bersumber pada masyarakat.

Berdasarkan kriteria ketuntasan minimal (KKM) yang telah ditentukan yaitu 67, hanya ada empat siswa yang mampu melampaui KKM dan selebihnya yaitu delapan siswa belum dapat mencapai KKM yang telah ditentukan yaitu 67. Berkaitan dengan hal tersebut maka diperlukan suatu metode pembelajaran yang mampu memfasilitasi siswa untuk mendapatkan pengalaman belajar yaitu metode yang memuat pengalaman belajar dan keaktifan siswa dalam kegiatan belajar mengajar.

Salah satu model pembelajaran yang diperkirakan mampu mengaktifkan siswa dalam belajar sehingga pembelajaran menjadi aktif, kreatif, efektif dan menyenangkan dan pada akhirnya dapat meningkatkan hasil belajar siswa adalah model pembelajaran kooperatif (cooverative learning). Pembelajaran dengan menggunakan model pembelajaran kooperatif, setiap siswa dituntut untuk belajar secara aktif. Keaktifan seluruh siswa merupakan kunci keberhasilan pembelajaran menggunakan model pembelajaran kooperatif, sehingga pembelajaran menjadi aktif, kreatif dan menyenangkan hal tersebut menyebabkan hasil belajar siswa meningkat. Penggunaan model pembelajaran kooperatif sangat tepat karena media pembelajaran yang menuntut siswa aktif, kreatif dan dan inovatif dan pada akhirnya hasil belajar siswa meningkat. Bedasarkan masalah yang berhasil diidentifikasi maka masalah dalam 


\section{JURNAL ILMIAH}

BINA EDUKASI

ISSN 1979-8598 E-ISSN: 2655-8378

$\frac{\text { http://journal.binadarma.ac.id/index.php/jurnalbinaedukasi }}{\text { Vol. 12, No. 2, Desember 2019, } 01-15}$

penelitian ini dapat dirumuskan sebagai berikut:"Apakah penggunaan model pembelajaran kooperatif dapat meningkatkan hasil belajar IPS pada siswa kelas V SDN 07 Indralaya Utara?.

\section{METODOLOGI PENELITIAN}

\subsection{Pengertian Ilmu Pengetahuan Sosial}

IPS merupakan salah satu mata pelajaran yang tercantum di dalam standar isi kurikulum 2006 KTSP. IPS adalah suatu bahan kajian yang terpadu yang merupakan penyederhanaan adaptasi, seleksi, dan modifikasi yang diorganisasikan dari konsep-konsep dan keterampilanketerampilan sejarah, geografi, sosiologi, antropologi, dan ekonomi, (Kasim, 2008).

\subsection{Pengertian Hasil Belajar}

Hasil pembelajaran adalah semua efek yang dapat dijadikan sebagai indikator tentang nilai dari penggunaan strategi pembelajaran di bawah kondisi yang berbeda". Sedangkan menurut Ernely (2014) menyebutkan bahwa "hasil belajar merupakan prestasi belajar peserta didik secara keseluruhan yang menjadi indikator kompetensi dasar dan derajat perubahan perilaku yang bersangkutan".

Dari kutipan di atas dapat dilihat bahwa setiap pembelajaran akan menghasilkan suatu hasil belajar yang sesuai atau tidak sesuai dengan indikator yang ditetapkan. Lebih lanjut (Wena, 2009 dalam Ernely, 2014) mengklasifikasikan variabel hasil pembelajaran menjadi tiga sebagai berikut.

1. Keaktifan (Effectveness) yang diukur dari tingkat pencapaian siswa yang selanjutnya dikategorikan menjadi empat indikator sebagai berikut.
(a) kecermatan penguasaan perilaku yang dipelajari;
(b) kecepatan unjuk kerja;
(c) tingkat alih belajar dan
(d) tingkat retensi.

2. Efisiensi (Efficiency) diukur dengan perbandingan antara keefektifan dan jumlah waktu yang dipakai siswa dan/atau jumlah biaya yang digunakan dalam pembelajaran.

3. Daya tarik diukur dengan mengamati kecenderungan siswa untuk tetap/terus belajar.

Penilaian hasil belajar tingkat sekolah atau satuan pendidikan bertujuan menilai pencapaian standar kompetensi lulusan untuk semua mata pelajaran. Penilaian hasil belajar oleh satuan pendidikan dilakukan pada akhir program pendidikan. Bahan-bahan yang diujikan meliputi seluruh materi standar kompetensi dan kompetensi dasar yang telah diberikan. 


\section{JURNAL ILMIAH}

BINA EDUKASI

ISSN 1979-8598 E-ISSN: 2655-8378

http://journal.binadarma.ac.id/index.php/jurnalbinaedukasi

Vol. 12, No. 2, Desember 2019, 01 -- 15

\subsection{Model Pembelajaran Kooperatif}

Sukiman (2013) mengatakan bahwa model pembelajaran kooperatif berasal dari kata cooperative yang artinya mengerjakan sesuatu secara bersama-sama dengan saling membantu satu sama lainnya sebagai satu kelompok atau satu tim. Sejalan dengan itu (Ernely,2014) mengemukakan bahwa "pembelajaran kooperatif (cooperative learnig) merupakan bentuk pembelajaran dengan cara siswa belajar dan bekerja dalam kelompok-kelompok kecil secara kolaboratif yang anggotanya terdiri dari empat sampai enam dengan struktur kelompok yang bersifat heterogen, dimana siswa dapat bekerja dan belajar bersama dalam sebuah kelompok untuk menyelesaikan tugas secara bersama dan saling membantu dalam kelompoknya, sehingga aktivitas belajar menjadi meningkat dan akan berpengaruh pada hasil belajar siswa. Ernely (2014) mengatakan bahwa dalam kegiatan pembelajaran, guru memegang peranan penting dalam menciptakan lingkungan yang mendukung aktivitas belajar siswa, sehingga merasa mampu mengatasi masalah mereka dan merasa dihargai. Kerja kelompok yang kooperatif dapat membantu meningkatkan rasa tenang, sikap positif serta pemahaman terhadap pekerjaannya maupun terhadap dirinya sendiri. Untuk mendapatkan manfaat dari aktivitas kerja kelompok yang kooperatif, siswa diberi kesempatan untuk mengembangkan berbagai keterampilan, semua siswa mempunyai kesempatan yang sama dalam proses pembelajaran. Adapun langkah-langkah dalam model pembelajaran kooperatif menurut Ibrahim dalam Ernely (2014) seperti tertera dalam tabel 1 di bawah ini.

Tabel 1. Langkah-langkah Model Pembelajaran Kooperatif

\begin{tabular}{ll}
\hline \multicolumn{1}{c}{ Fase } & \multicolumn{1}{c}{ Tingkah Laku Guru } \\
\hline $\begin{array}{l}\text { Fense-1 } \\
\text { memotivasi siswa }\end{array}$ & $\begin{array}{l}\text { Guru menyampaikan semua tujuan pembelajaran } \\
\text { yang ingin dicapai pada pelajaran tersebut dan } \\
\text { memotivasi siswa belajar }\end{array}$ \\
$\begin{array}{l}\text { Fase-2 } \\
\text { Menyajikan Informasi }\end{array}$ & $\begin{array}{l}\text { Guru menyampaikan informasi kepada siswa dengan } \\
\text { jalan demontrasi atau lewat bahan bacaan }\end{array}$ \\
& $\begin{array}{l}\text { Guru menjelaskan kepada siswa bagaimana caranya } \\
\text { membentuk kelompok belajar dan membantu setiap }\end{array}$ \\
$\begin{array}{l}\text { Mengo-3 } \\
\text { kelompok-kelompok belajar }\end{array}$ & kelompok agar melakukan transisi secara efisien \\
$\begin{array}{l}\text { Fase-4 } \\
\text { Membimbing kelompok bekerja dan } \\
\text { belajar }\end{array}$ & $\begin{array}{l}\text { Guru membimbing kelompok-kelompok belajar pada } \\
\text { saat mereka mengerjakan tugas mereka }\end{array}$ \\
$\begin{array}{l}\text { Fase-5 } \\
\text { Evaluasi }\end{array}$ & $\begin{array}{l}\text { Guru mengevaluasi hasil belajar tentang meteri yang } \\
\text { telah dipelajari atau masing-masing kelompok } \\
\text { mempresentasikan hasil kerjanya }\end{array}$ \\
$\begin{array}{l}\text { Fase-6 } \\
\text { Memberikan penghargaan }\end{array}$ & Guru mencari cara-cara untuk menghargai baik upaya \\
\hline
\end{tabular}


BINA EDUKASI

ISSN 1979-8598 E-ISSN: 2655-8378

http://journal.binadarma.ac.id/index.php/jurnalbinaedukasi

Vol. 12, No. 2, Desember 2019, 01 -- 15

\subsection{Langkah-langkah Model Pembelajaran Kooperatif}

Berikut adalah langkah-langkah model pembelajaran kooperatif:

1. Guru menyampaikan semua tujuan pembelajaran yang ingin dicapai pada pelajaran tersebut dan memotivasi siswa belajar;

2. Guru menyampaikan informasi kepada siswa dengan jalan demonstrasi atau lewat bahan bacaan;

3. Guru menjelaskan kepada siswa bagaimana caranya membentuk kelompok belajar dan membantu setiap kelompok agar melakukan transisi secara efisien;

4. Guru membimbing kelompok-kelompok belajar pada saat mereka mengerjakan tugas mereka;

5. Guru mengevaluasi hasil belajar tentang meteri yang telah dipelajari atau masingmasing kelompok mempresentasikan hasil kerjanya;

6. Guru mencari cara-cara untuk menghargai baik upaya maupun hasil belajar individu dan kelompok.

Proses pembelajaran yang terjadi di sini senantiasa merupakan proses kegiatan interaksi antara dua unsur manusia, yakni siswa sebagai pihak yang belajar dan guru sebagai pihak yang mengajar. Dalam proses interaksi ini antara siswa dan guru dibutuhkan komponen-komponen pendukung yang dalam proses pembelajaran tidak dapat dipisah-pisahkan. Faktor pendukung tersebut mempunyai ciri-ciri diantaranya ada tujuan yang hendak dicapai, ada bahan yang menjadi isi interaksi, ada siswa yang mengalami, ada guru yang membimbing, ada metode mencapai tujuan, ada situasi yang memungkinkan dan ada penilaian hasil interaksi. Dengan demikian dalam pembelajaran kooperatif terjadi saling ketergantungan yang positif antar siswa dengan siswa, siswa dengan guru dan siswa sebagai pusat sumber belajar.

\subsection{Kelebihan dan Kekurangan Model Pembelajaran Kooperatif}

Adapun kelebihan model pembelajaran kooperatif menurut Hill and Hill (dalam Hobri, 2009) sebagai berikut.

a) Meningkatkan prestasi siswa;

b) Memperdalam pemahaman siswa;

c) Menyenangkan siswa;

d) Mengembangkan sikap kepemimpinan;

e) Mengembangkan sikap positif siswa;

f) Mengembangkan sikap menghargai diri sendiri;

g) Membuat belajar secara inklusif;

h) Mengembangkan rasa saling mememiliki;

i) Mengembangkan keterampilan masa depan. 


\section{JURNAL ILMIAH}

BINA EDUKASI

ISSN 1979-8598 E-ISSN: 2655-8378

http://journal.binadarma.ac.id/index.php/jurnalbinaedukasi

Vol. 12, No. 2, Desember 2019, 01 -- 15

Sedangkan kelemahan dari model pembelajaran kooperatif menurut Dess (dalam Hobri, 2009) sebagai berikut.

a) Membutuhkan waktu yang lama bagi siswa, sehingga sulit untuk mencapai target kurikulum;

b) Membutuhkan waktu yang lama bagi guru sehingga kebanyakan guru tidak mau menggunakan strategi pembelajaran kooperatif;

c) Membutuhkan keterampilan khusus guru sehingga tidak semua guru dapat melakukan atau menggunakan strategi pembelajaran kooperatif;

d) Menuntut sifat tertentu dari siswa, misalnya sifat suka bekerja sama.

\subsection{Tempat dan Waktu Penelitian}

Penelitian ini dilakukan di SD Negeri 07 Indralaya Utara yang beralamat di Desa Parit Kecamatan Indralaya Utara Kabupaten Ogan Ilir Provinsi Sumatera Selatan. Adapun waktu penelitian dilakukan pada Bulan Oktober 2019.

\subsection{Subjek Penelitian}

Subjek penelitian adalah siswa Kelas V SDN 07 Indralaya Utara, dengan jumlah siswa laki-laki sebanyak lima orang dan siswa perempuan sebanyak tujuh orang. Siswa kelas ini dijadikan sebagai kelas penelitian karena hasil belajar di kelas ini lebih rendah, hal ini terlihat dari hasil ulangan harian kelas ini masih banyak yang belum mencapai kriteria ketuntasan minimal.Selain itu kegiatan belajar mengajar terlihat lebih pasif dan terkesan membosankan.

\subsection{Desain Penelitian}

Prosedur penelitian menggunakan prosedur Alur dari model Elliot diadopsi dari Atmono (2009), pada intinya akan mengidentifikasi perkembangan dan perubahan subjek setelah subjek diberikan perlakuan khusus atau dikondisi tertentu dalam kurun waktu tertentu dan berulang-ulang sampai program dinyatakan berhasil. Setiap siklus mencakup empat tahapan, yaitu perencanaan(planning), pelaksanaan tindakan (action), pengamatan (observasi), dan refleksi, (reflection). Berikut penjelasan dari masing-masing siklus:

\section{1) Perencanaan Tindakan}

Sebelum tindakan aktual dilaksanakan dalam pembelajaran di kelas, terlebih dahulu dilakukan persiapan secara baik, antara lain:

a) Membuat skenario pembelajaran dengan penggunaan model pembelajaran kooperatif yang berisi langkah-langkah kegiatan pembelajaran IPS dengan standar kompetensi menghargai berbagai peninggalan dan tokoh sejarah yang berskala nasional pada masa Hindu-Budha dan Islam, keragaman akan alam dan suku bangsa serta kegiatan ekonomi di Indonesia. 


\section{JURNAL ILMIAH}

BINA EDUKASI

ISSN 1979-8598 E-ISSN: 2655-8378

http://journal.binadarma.ac.id/index.php/jurnalbinaedukasi

Vol. 12, No. 2, Desember 2019, 01 -- 15

b) Menyiapkan sarana prasarana pembelajaran yang mendukung terlaksananya tindakan pembelajaran, seperti buku sumber rujukan,menyusun materi ajar,whiteboard, kertas, spidol, menyiapkan nomor dan lain sebagainya.

c) Menyiapkan instrumen kreativitas siswa dalam pembelajaran dan indikator tes hasil belajar.

d) Mendeskripsikan secara jelas peran guru sebagai pemberi tindakan dan peran kolaborator sebagai observer serta peran siswa sebagai subyek dalam pembelajaran.Melakukan pelaksanaan tindakan dan menguji keterlaksanaannya di kelas. Adapun kegiatan persiapannya sebagai berikut.

1) Membuat pemetaan standar isi

2) Membuat analisis SK dan KD

3) Membuat Silabus Pembelajaran

4) Membuat rencana pembelajaran

5) Menyiapkan materi ajar

6) Menjelaskan tentang model pembelajaran kooperatif

Sedangkan kegiatan dalam pelaksanaan pembelajarannya sebagai berikut.

1) Membagikan materi ajar

2) Melaksanakan rencana pelaksanaaan pembelajaran sesuai dengan materi pembelajaran

3) Membagikan lembar soal dan lembar kerja perkelompok

4) Melakukan penilaian selama proses pembelajaran

5) Melakukan evaluasi pembelajaran diakhir diakhir siklus

6) Memberikan penguatan (reward) diakhir pembelajaran

7) Menutup pembelajaran dengan memberikan tindak lanjut

\section{2) Pelaksanaan Tindakan}

Melaksanakan seluruh rencana yang telah dibuat pada tahap sebelumnya, dan melaksanakan langkah-langkah baru secara fleksibel yang dianggap penting dalam setiap kegiatan yang telah direncanakan, termasuk dalam menyajikan materi pelajaran sesuai dengan skenario yang telah dibuat atau dikembangkan sesuai kebutuhan pembelajaran. Adapun langkah-langkah model pembelajaran kooperatif sebagi berikut.

1. Guru menyampaikan semua tujuan pembelajaran yang ingin dicapai pada pelajaran tersebut dan memotivasi siswa belajar

2. Guru menyampaikan informasi kepada siswa dengan jalan demontrasi atau lewat bahan bacaan

3. Guru menjelaskan kepada siswa bagaimana caranya membentuk kelompok belajar dan membantu setiap kelompok agar melakukan transisi secara efisien 


\section{JURNAL ILMIAH}

BINA EDUKASI

ISSN 1979-8598 E-ISSN: 2655-8378

$\frac{\text { http://journal.binadarma.ac.id/index.php/jurnalbinaedukasi }}{\text { Vol. 12, No. 2, Desember 2019, } 01-15}$

4. Guru membimbing kelompok-kelompok belajar pada saat mereka mengerjakan tugas mereka

5. Guru mengevaluasi hasil belajar tentang meteri yang telah dipelajari atau masingmasing kelompok mempresentasikan hasil kerjanya

6. Guru mencari cara-cara untuk menghargai baik upaya maupun hasil belajar individu dan kelompok

Rencana kegiatan yang telah dirancang pada rencana pelaksanaan pembelajaran, sebagai skenario pembelajaran dilaksanakan dalam proses pembelajran siswa di dalam kelas. Setiap tatap muka menggunakan media gambar dengan urutan tindakan sebagai berikut.

a. Kegiatan awal:

$>$ Guru mempersiapkan media pembelajaran yaitu berupa power point yang di tayangkan dengan menggunakan proyector.

> Guru melakukan tanya jawab untuk mengetahui kemampuan awal siswa mengenai materi keanekaragaman budaya bangsa Indonesia.

Guru menyampaikan tujuan pembelajaran

> Guru menyampaikan topik yang akan dipelajari mengenai materi keanekaragaman budaya di Indonesia

Guru membagi siswa menjadi empat kelompok

b. Kegiatan inti :

Guru menjelaskan secara singkat proses pembelajaran yang akan berlangsung

Mengorganisasikan siswa ke dalam bentuk kelompok yang terdiri dari tiga sampai dengan lima orang yang bersifat heterogen menjadi empat tim kelompok.

> Guru membagikan lembar kerja diskusi pada setiap kelompok.

Guru menjelaskan tugas kelompok yang akan dilaksanakan siswa.

Siswa dengan bimbingan guru mendiskusikan dan membahas materi yang telah dibagikan.

Setelah selesai diskusi sesuai dengan waktu yang telah ditentukan masing-masing kelompok mempresentasikan hasil diskusi di depan kelas dengan perwakilan setiap pakarnya, sedangkan kelompok lain diberi kesempatan untuk memberi komentar.

Membantu membenarkan kesimpulan hasil pembelajaran yang diperoleh siswa, jika belum benar.

Guru memberi penghargaan kepada kelompok dengan kinerja bagus.

Evaluasi. Setelah dua kali pertemuan pembelajaran dengan menggunakan model kooperatif, kemudian diadakan ulangan harian dengan menggunakan tes bentuk 


\section{JURNAL ILMIAH}

BINA EDUKASI

ISSN 1979-8598 E-ISSN: 2655-8378

http://journal.binadarma.ac.id/index.php/jurnalbinaedukasi

Vol. 12, No. 2, Desember 2019, 01 -- 15

essay sebanyak lima butir soal, data hasil ulangan harian tersebut dianalisis guna untuk mengukur hasil belajar siswa pada siklus I.

c. Kegiatan akhir:

Guru bersama siswa menyimpulkan pembelajaran.

Guru memberikan tes formatif sebanyak lima soal.

Guru memberikan tugas kepada siswa untuk memperhatikan tingkat pemahaman siswa mengenai materi yang telah di pelajari.

\section{3) Observasi}

Observasi dilakukan untuk merekam proses kegiatan dan dampak proses yang terjadi selama pembelajaran berlangsung. Pelaksanaan observasi menyatu dengan kegiatan tindakan, pengamatan dan refleksi sebagai suatu proses pembelajaran yang utuh. Observasi yang dilakukan oleh seorang guru.

Peran guru sebagai kolaborator bertugas untuk memberikan pengamatan terhadap proses pembelajaran siswa dalam kegiatan belajar mengajar yang mencakup : Lembar obsevasi kreativitas siswa dalam belajar.

Selama proses pembelajaran berlangsung aktivitas siswa dalam kelompok diskusi diamati terus oleh penulis dan observer, yang terlibat dalam penelitian ini selama dua kali pertemuan dalam proses pembelajan untuk satu siklus. Alat pengumpul data berupa lembar observasi dan diakhir pembelajaran dilakukan penilaian hasil belajar untuk dievaluasi dan dianalisis diakhir siklus sebagai bahan pertimbangan dalam menentukan kegiatan pembelajaran siklus berikutnya.

\section{4) Refleksi}

Refleksi dilakukan dengan tujuan untuk mengetahui letak kekurangan selama kegiatan dengan penggunaan model pembelajaran kooperatif, dan untuk mengetahui kekurangan pelaksanaan persiklus penulis menyiapkan tes hasil belajar dan instrumen kreativitas siswa dalam belajar.Data yang diperoleh adalah untuk mengetahui hasil belajar siswa pada mata pelajaran IPS materi suku bangsa di Indonesia juga untuk mengetahui aktivitas siswa selama pembelajaran berlangsung selama dua kali tatap muka.

\subsection{Metode Pengumpulan Data}

Pengumpulan data dilakukan dengan menggunakan observasi dan tes yang digunakan dalam penelitian ini terdiri atas:

1. Lembar observasi, yaitu data dikumpulkan dengan cara mengamati aktivitas siswa selama proses pembelajarandengan menggunakan media gambar. 


\section{JURNAL ILMIAH}

BINA EDUKASI

ISSN 1979-8598 E-ISSN: 2655-8378

$\frac{\text { http://journal.binadarma.ac.id/index.php/jurnalbinaedukasi }}{\text { Vol. 12, No. 2, Desember 2019, } 01 \text {-- } 15}$

2. Tes, yaitu indikator tes digunakan untuk mengumpulkan data tentang hasil belajar siswa setelah proses pembelajaran dengan media gambar. Tes yang digunakan oleh penulis adalah tes tertulis dalam bentuk soal pilihan ganda.Tes digunakan untuk memperoleh hasil belajar sesuai ketuntasan minimalnya, soal tes yang diberikan berdasarkan materi yang sudah disampaikan. Tes dilakukan dua kali, tes pertama yaitu tes yang diberikan pada akhir siklus I dan tes kedua yaitu tes yang diberikan pada akhir siklus II.Hasil belajar siswa diukur berdasarkan bukti-bukti yang didapat dari hasil observasi dan tes yang diberikan.

\subsection{Metode Analisa Data}

Metode analisa data menggunakan rumus teknik proporsi (Sudjana, 2010), yaitu.

$$
\mathrm{D}=[\mathrm{A} / \mathrm{N}] \times 100 \%
$$

Keterangan:

D : $\quad$ Prosentase siswa yang tuntas

A : Jumlah siswa yang tuntas

$\mathrm{N}$ : Jumlah seluruh siswa

Indikator keberhasilan dalam penelitian ini adalah jika $80 \%$ atau lebih siswa kelas $\mathrm{V}$ SDN 07 Indralaya Utara memperoleh nilai sama atau melebihi nilai standar minimum 67 untuk materi yang diajarkan.Persentase keberhasilan pencapaian hasil belajar siswa tersebut ditentukan dengan acuan dari Fatimah (2008) sebagai berikut.

Tabel 2. Indikator Keberhasilan Nilai Akhir Siswa

\begin{tabular}{|c|c|c|}
\hline No. & $\begin{array}{c}\text { Prosentase } \\
\text { Ketuntasan }\end{array}$ & Katagori \\
\hline 1 & $\geq 80 \%$ & Sangat tinggi \\
\hline 2 & $70 \%-79 \%$ & Tinggi \\
\hline 3 & $60 \%-69 \%$ & Cukup \\
\hline 4 & $50 \%-59 \%$ & Kurang \\
\hline 5 & $\leq 49$ & Sangat kurang \\
\hline
\end{tabular}

Sumber: Fatimah (2008)

Sebagai data pendukung penelitian, ditetapkan juga indikator keberhasilan untuk melihat aktivitas siswa, dengan pengamatan terhadap aktivitas positif dan negatif.

Persentase aktivitas positif ditentukan dengan acuan dari Arikunto (1993) yaitu, 76 \%-$100 \%$ aktivitas baik sekali (BS), $51 \%--75 \%$ aktivitas baik (B), $26 \%--50 \%$ aktivitas sedang 
(S) dan $1 \%--25 \%$ aktivitas kurang (K). Sedangkan persentase aktivitas negatif siswa ditentukan dengan acuan Slameto (1999) yaitu 0\% baik sekali (B), $1 \%--10 \%$ cukup baik (CB), $11 \%--25 \%$ cukup (C), $26 \%$--49 \% kurang (K), $50 \%--100 \%$ dan kurang sekali (KS).

Teknik analisa data menggunakan teknik proporsi (Sudjana,2001) diawali dengan kegiatan penskoran terhadap jumlah jawaban penskoran. Skor dianalisis untuk mengetahui hasil belajar siswa dengan menggunakan formula:

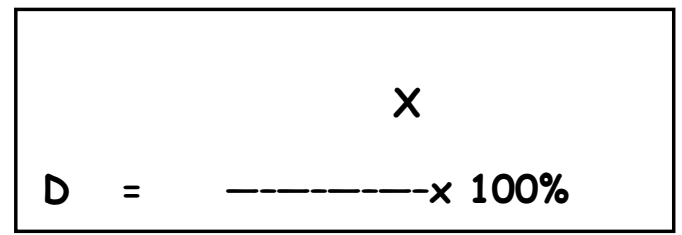

Keterangan: $\quad \mathrm{D}=$ Presentase hasil belajar siswa

$\mathrm{X}=$ Jumlah siswa yang Tuntas

$\mathrm{N}=$ Jumlah seluruh siswa

Dan untuk aktivitas rata- rata belajar siswa $A=\{Y / N\} X 100 \%$

Keterangan: $\quad \mathrm{A}=$ Prosentase aktivitas rata belajar siswa

$\mathrm{Y}=$ Jumlah aktivitas positif atau aktivitas negatif

$\mathrm{N}=$ Jumlah total siswa

\section{HASIL DAN PEMBAHASAN}

\subsection{Hasil}

\subsubsection{Siklus I}

Hasil penelitian pada siklus I berupa data hasil olah nilai tes terhadap siswa diakhir siklus I untuk memperoleh nilai hasil belajar siswa selama dua kali pertemuan.

Tabel 3. Hasil Belajar Siswa pada Akhir Siklus I

\begin{tabular}{ccccc}
\hline No. & Nilai & $\begin{array}{c}\text { Jumlah } \\
\text { Siswa }\end{array}$ & Tercapai & $\begin{array}{c}\text { Tidak } \\
\text { Tercapai }\end{array}$ \\
\hline 1. & $<49$ & 2 & - & $\checkmark$ \\
2. & $50-59$ & 1 & - & $\checkmark$ \\
3. & $60-69$ & 2 & - & $\checkmark$ \\
4. & $70-79$ & 4 & $\checkmark$ & - \\
5. & $80-89$ & 1 & $\checkmark$ & - \\
6. & $90-100$ & 2 & $\checkmark$ & - \\
\hline & Jumlah & 12 & 7 & 5 \\
\hline
\end{tabular}




\section{JURNAL ILMIAH}

BINA EDUKASI

ISSN 1979-8598 E-ISSN: 2655-8378

http://journal.binadarma.ac.id/index.php/jurnalbinaedukasi

Vol. 12, No. 2, Desember 2019, 01 -- 15

Berdasarkan tabel 3 di atas menunjukkan hasil belajar siswa setelah siklus 1 telah memenuhi standar ketuntasan belajar minimum 67 sebesar 58,33\% . Nilai siswa pada 70--79 dengan nilai rata-rata 40\%. Nilai siswa tidak menyebar merata, kisaran 80--89 dengan nilai ratarata 8,33\% dan kisaran 90--100 dengan nilai 16,67\% maka dapat dikatakan pada siklus I hasil belajar siswa belum optimal dan oleh karena itu perlu ditingkatkan pada siklus selanjutnya. Indikator keberhasilan nilai siswa adalah dua orang siswa dengan nilai sangat kurang, satu orang siswa dengan kurang, dua orang siswa memperoleh nilai cukup, empat orang siswa memperoleh nilai tinggi dan tiga orang siswa memperoleh nilai sangat tinggi rata-rata siswa memperoleh nilai tinggi jadi jumlah siswa yang telah melampaui KKM 67 sebanyak tujuh orang siswa dengan presentase ketuntasan adalah 58,33\%, sehingga dapat dikatakan kurang.

\subsubsection{Siklus II}

Data yang diperoleh dalam siklus II berupa data hasil olah nilai tes terhadap siswa di akhir siklus II untuk memperoleh nilai hasil belajarnya.

Tabel 4. Data Hasil Belajar Siswa pada Akhir Siklus II

\begin{tabular}{ccccc}
\hline No. & Nilai & $\begin{array}{c}\text { Jumlah } \\
\text { Siswa }\end{array}$ & Tuntas & $\begin{array}{c}\text { Tidak } \\
\text { Tuntas }\end{array}$ \\
\hline 1. & $<49$ & - & - & - \\
2. & $50-59$ & - & - & - \\
3. & $60-69$ & 2 & - & 2 \\
4. & $70-79$ & 1 & 1 & - \\
5. & $80-89$ & 4 & 4 & - \\
6. & $90-100$ & 5 & 5 & - \\
\hline & Jumlah & 12 & 10 & - \\
\hline
\end{tabular}

Berdasarkan tabel 4 di atas menunjukkan hasil belajar siwa setelah siklus II telah memenuhi standar ketuntasan belajar minimum 80 sebesar $83,33 \%$. Nilai siswa sebagian besar pada kisaran 80--89 dengan nilai 33,33\% yang dikategorikan tinggi, jadi jumlah siswa yang mencapai nilai KKM 67 adalah sebanyak sepuluh orang siswa dengan presentase ketuntasan adalah 83,33\% maka dapat dikatakan pada siklus II hasil belajar siswa sudah optimal. Indikator keberhasilan nilai siswa yaitu sebanyak dua orang siswa dengan nilai tinggi dan sepuluh orang siswa memperoleh nilai sangat tinggi, rata-rata siswa memperoleh nilai tinggi, sehingga jumlah siswa tuntas yaitu sebanyak sepuluh orang siswa dengan presentase ketuntasan adalah $83,33 \%$ berkategori sangat tinggi. 


\subsection{Pembahasan}

\subsubsection{Hasil Penelitian Peningkatan Hasil Belajar Siswa Akhir Siklus I dan Siklus II}

Proses pembelajaran yang telah dilakukan, telah mengarah pada peningkatan keaktifan belajar siswa dan akhirnya berpengaruh pada hasil belajar siswa. Berdasarkan data nilai yang diperoleh dari tes yang diberikan pada siswa pada akhir setiap siklus pada penelitian tindakan kelas ini, pembelajaran dengan model pembelajaran kooperatif menunjukkan adanya peningkatan pada hasil belajar siswa.Peningkatan hasil belajar siswa pada mata pelajaran IPS secara jelas dapat dilihat pada tabel berikut ini.

Tabel 5. Data Peningkatan Hasil Belajar Siswa pada Akhir Siklus I dan Siklus II

\begin{tabular}{ccccc}
\hline No. & $\begin{array}{c}\text { Prosentase } \\
\text { Ketuntasan }\end{array}$ & Kategori & $\begin{array}{c}\text { Nilai Akhir } \\
\text { Siklus I }\end{array}$ & $\begin{array}{c}\text { Nilai Akhir } \\
\text { Siklus II }\end{array}$ \\
\hline 1. & $\geq 80 \%$ & Sangat tinggi & 3 & 9 \\
2. & $70 \%-79 \%$ & Tinggi & 4 & 1 \\
3. & $60 \%-69 \%$ & Cukup & 2 & 2 \\
4. & $50 \%-59 \%$ & Kurang & 1 & 0 \\
5. & $\leq 49$ & sangat kurang & 2 & 0 \\
\hline
\end{tabular}

Pada siklus I indikator keberhasilan nilai siswa menunjukkan jumlah siswa yang telah tuntas mencapai KKM 67 yaitu sebanyak tujuh orang siswa dengan presentase ketuntasan klasikal adalah 58,33\% dan berkategori kurang. Sedangkan pada siklus II indikator keberhasilan nilai siswa yang telah tuntas mencapai KKM 67 yaitu sebanyak sepuluh orang siswa dengan presentase ketuntasan klasikal adalah $83,33 \%$ dan berkategori sangat tinggi. Indikator keberhasilan adalah 83,33\% siswa mencapai KKM 67. Sedangkan dalam penelitian ini menunjukkan sebanyak 83,33\% siswa telah mencapai KKM, sehingga dapat dikatakan bahwa penelitian ini telah berhasil meningkatkan hasil belajar IPS melalui model pembelajaran kooperatif.

Tabel 6. Peningkatan Hasil Belajar

\begin{tabular}{ccc}
\hline Penelitian & Tercapai \% & $\begin{array}{c}\text { Tidak } \\
\text { Tercapai \% }\end{array}$ \\
\hline Pra Penelitian & 4 & 8 \\
Akhir Siklus I & 7 & 5 \\
Akhir Siklus II & 10 & 2 \\
\hline
\end{tabular}




\section{JURNAL ILMIAH \\ BINA EDUKASI \\ ISSN 1979-8598 E-ISSN: 2655-8378 \\ http://journal.binadarma.ac.id/index.php/jurnalbinaedukasi \\ Vol. 12, No. 2, Desember 2019, 01 -- 15}

Berdasarkan tabel 6 di atas, dapat dilihat hasil peningkatan ketuntasan secara klasikal pra penelitian dengan persentase sebesar 33,33\% pada siklus I terjadi peningkatan hasil belajar menjadi 58,33\%, pada siklus II menjadi $83,33 \%$, sehingga pembelajaran dengan model kooperatif dapat dinyatakan berhasil karena sudah mencapai tingkat ketuntasan sebesa $100 \%$. Adapun peningkatan hasil belajar yang terjadi tersebut dikarenakan siswa lebih cepat mengingat materi pelajaran dengan menggunakan model kooperatif dan proses pembelajaran disesuaikan dengan rencana pelaksanaan pembelajaran yang telah disusun. Selain itu, siswa juga terlihat sangat terbantu dengan adanya model pembelajaran seperti ini. Dalam proses pembelajaran siswa dapat mendengar, melihat dan mencari sendiri jawaban dari permasalahan yang mereka hadapi yang pada akhirnya mereka dapat dengan mudah menyelesaikan permasalahan dan soalsoal yang diberikan dengan penerapan pembelajaran ini. Dengan demikian tampak bahwa penerapan model pembelajaran kooperatif dapat meningkatkan hasil belajar siswa pada mata pelajaran IPS. Bilamana guru bermaksud agar siswa-siswa mencapai studi yang mendalam tentang isi atau materi, yang tidak dapat dipahami secara memadai dari sajian-sajian informasi yang terpusat pada guru. Namun bilamana guru bermaksud mendorong siswa untuk lebih kritis tentang ide-ide yang disajikan dari fakta-fakta yang mereka dapatkan.

\section{SIMPULAN}

Penggunaan metode pembelajaran kooperatif di kelas V SDN 07 Indralaya Utara dapat meningkatkan hasil belajar siswa. Dari data yang telah dibahas pada siklus 1 dengan hasil belajar tuntas $58,33 \%$ tidak tuntas $41,66 \%$ prosentase keberhasilan belajar siklus 1 adalah $58,33 \%$ peningkatan hasil belajar siklus 2 diperoleh hasil belajar dengan rincian ketuntasan hasil belajar $83,33 \%$ yang tidak tuntas $16,67 \%$ peningkatan dari siklus 1 , dan indikator keberhasilan adalah $80 \%$, jadi dapat disimpulkan bahwa model pembelajaran tipe kooperatif dapat meningkatkan hasil belajar siswa pada mata pelajaran ilmu pengetahuan sosial (IPS). Oleh karena itu disarankan kepada guru untuk menggunakan model pembelajaran kooperatif sebagai variasi pembelajaran IPS atau mata pelajaran lain. Penerapan model kooperatif untuk memberikan kesempatan kepada siswa agar dapat terlibat secara aktif dalam proses berpikir dan dalam kegiatan-kegiatan belajar artinya pembelajaran benar benar berfokus pada siswa.

\section{DAFTAR PUSTAKA}

Arikunto,S. 1993. Prosedur Penelitian suatu Pendekatan Praktik. Jakarta: Rineka Cipta.

Atmono, Dwi. 2009. Penelitian Tindakan Kelas. Kalimantan Selatan: Scripta Cendekia. 
Ernely. 2014. Meningkatkan Aktivitas Belajar IPA Siswa Kelas VI SD Negeri Simpang Pelabuhan dalam Melalui Model Pembelajaran Kooperatif dengan Metode Tutor Sebaya. Jakarta: Pustaka Jaya.

Fatimah, Siti. 2008. Modul Model-Model Pembelajaran SMP dan SMA. Palembang: Universitas Sriwijaya.

Hobri. 2009. Model Pembelajaran Kooperatif Learning. (Online).(http://abdulgopuroke.blogspot.com/2017/01/kelebihan-kekurangan-modelpembelajaran-kooperatif.html). Diunduh tanggal 14 Oktober 2018.

Kasim, Ahmad. 2008. Pengertian IPS dalam Model Pembelajaran Kooperatif Learning. Jakarta : Permendiknas.

Slameto. 1999. Proses Belajar Mengajar. Jakarta: Bumi Aksara.

Sudjana. 2001. Metode dan Teknik Pembelajaran Partisipatif. Bandung: Falah Production.

Sudjana. 2010. Metode Statistik. Jakarta: Rineka Cipta.

$\begin{array}{lllll}\text { Sukiman. } & \text { 2013. Skripsi Model PAKEM PTK. One) }\end{array}$ http://kimlawalangi.blogspot.com/2013/06/skripsi-model-pakem-ptk.html). Diunduh tanggal 10 Oktober 2018. 